\title{
Students Perception Of Teacher's Involvement In Academic Dishonesty
}

\author{
Dr. Blessing Ikiroma \\ Ignatius Ajuru University of Education, Rumuolumeni, Port Harcourt \\ Dr. Jerome Anyanwu \\ University of Port Harcourt, Choba, Port Harcourt
}

\begin{abstract}
This study examines the perception of senior secondary school students in Rivers State on the extent of teacher's involvement in academic dishonesty. Subjects were 1,000 senior secondary school students in Rivers State drawn via multi-stage sampling technique. Data for the study were obtained through a questionnaire on a simple yes or no format which has a reliability coefficient of 0.87 . Three research questions guided the study and frequency counts which were converted to simple percentages were deployed as statistical tools. The study revealed that a greater percentage of the students view their teachers as being involved very often in dishonest practices academically. The study also showed that inflation of continuous assessment/examination scores tops the lists in the views of the students' as one of the ways that teachers contribute to academic dishonesty. This is followed with conspiracy of teachers with both students and security officials during examination, exchange of answers for money, and teachers impersonating students in that order. Based on these findings it was recommended among others, that teachers should spend more time in preparing students for examinations. If they do it, is likely that teachers would not be intimidated by parents to do what they would not naturally want to do.
\end{abstract}

Key words: Secondary school students, Teachers, Academic Dishonesty, Rivers State

\section{INTRODUCTION}

In order to have high achievement among all student groups, and high public confidence in schools, there must be an acceptable method of measuring the achievement of students, which is capable of promoting public confidence in the school. Many people do not have confidence in the school system today due to many reasons. One of such reasons precincts on students' performance in public examinations. Another reason has to do with the moral standard (on academic matters) of students, teachers, head teachers, parents and the community in which the school is located. The concern is that if students are not able to perform well in their school subjects; they should fail nobly without any form of academic dishonesty. The term "academic dishonesty" according to the Guidelines for Academic Conduct from University of Saskatchewan Council (2003) includes both plagiarism and other forms of cheating, such as taking notes into an exam or lying about admission qualifications. This definition brings to mind concepts such as educational fraud, academic dishonesty and examination malpractice. However, in this paper academic dishonesty is used in accordance with the title of this study and due to the fact that the researchers perceived that academic dishonesty is wider in scope. There are media reports on an intermittent basis that shows the cancellation of examination papers by either National Examination Council (NECO) or the West African Examination Council (WAEC), of examination papers such as: English Language, Geography, Physics I and II, 
Mathematics, Chemistry I and II to mention but a few. This cast some doubts on the honesty and integrity of the examination body, teachers and students.

Teachers are important in the school setting (Federal Government of Nigeria (FGN), 2004). They constitute the principal agents that can ensure honesty and integrity in schools. In their ten Principles of Academic Integrity, Donald, Cabe and Pavela (2003) explained that teachers have primary responsibility for designing and cultivating the educational environment and experience. They must clarify their expectations in advance regarding honesty in academic work, including the nature and scope of student collaboration. Most students want such guidance, and welcome it in course syllabi, carefully reviewed by their teachers in class. Furthermore, with proper guidance by the teachers, students can be given significant responsibility to help protect and promote the highest standards of academic integrity. A high proportion of students want to work in settings, where competition is fair, integrity is respected, and cheating is punished. The Guidelines for Academic Conduct from University of Saskatchewan Council (2003) give the following description of honest behaviour at the university: Perform your own work unless specifically instructed otherwise. Use your own work to complete assignments and exams. Cite the source when quoting or paraphrasing someone else's work. Follow examination rules. Be truthful on all university forms. Discuss with your professor if you are using the same material for assignments in two different courses. Discuss with your professor if you have any questions about whether sources require citation. Use the same standard of honesty with fellow students, laboratory instructors, teaching assistants, seasonal instructors and administrative staff as you do with faculty (http://www.usask.ca/honesty).

Moreover, some students from the University of Saskatchewan made suggestions on ways to encourage academic honesty. Some suggestions for encouraging academic honesty are: Explain assignment clearly; Allot time for questions; Take more time to prepare students for exams; more review before mid-terms and exams; Follow the study guidelines and interactive testing (i.e., in tutorials) instead of papers or take-home tests; Reduce class size; Slow down the pace of delivering course material; Allow a reasonable amount of time to study for exams and prepare assignments; Less emphasis on grades and more pass/fail marking; Use other methods of evaluation besides exams; Give more assistance on where to find appropriate information, give examples of proper footnoting and quoting, and demonstrate what is considered plagiarism and what is not; Publicly expose cheaters. http://www.usask.ca/honesty.

Nevertheless, in a method class taught by one of the researchers of this study in 2016 in University of Port Harcourt, the students were asked what profession title was of initial interest to them, most students said they would like to be called doctors, pharmacists, engineers, architects, barrister, and so on as titles after their profession, but nobody will be willing to be called teacher. This implies that many people do not want to be called teachers because of the way society sees a teacher. The teachers themselves are not helping matters; they cheapen themselves in involving themselves in such degrading practices like aiding and abetting dishonest practices during examination because of transient reward.

With respect to the issue of teachers being corrupt, earlier study had indicated that some teachers (supervisors and invigilators) are corrupt. In the study of Makoju, Adewale, Nwargwu and Shuaibu (2004) they concluded that one of the social menaces the government and her agencies is fighting is the issue of corruption. Some people who have one thing or the other 
with examination are corrupt. They take bribe from students or harass female students sexually before they could allow them pass. Furthermore, Onuka and Obialo (2004) found out that invigilators conspire with both students and security officials during examinations to perpetuate cheating. Also the study by Science Teachers Association of Nigeria (STAN) in 2011 revealed that most teachers tend to inflate continuous assessment and examination scores. In addition, Adewale (2004) had earlier found out that teachers impersonate students. For instance, a candidate registers with his/her names but submits the photograph of another (the mercenary which could be a teacher) with whom arrangement has been made to take the examination on his/her behalf. In this arrangement, the candidate may enter another arrangement with the invigilator to replace the mercenary's photographs with his/her own or the mercenary submits a poorly taken photograph, which will fade within a few months of production. When they fade and replacement is demanded, those of the original candidate are now submitted. These results do not seem to portend well with the school system, especially when viewed from the point of view of the fact that teachers are expected to be character molders.

Parents are not helping teachers' integrity, even when some teachers are not willing to comprise their stand; some parents entice them to do what they do not want to do. There is a specific case, in which due to the craze for paper qualification, a parent bought JAMB result for his son to read medicine, however, he bought a wrong combination. He went with his son to show the result to a professor in one of the leading universities in Nigeria and the professor said, "Your child won't be able to read medicine because of wrong combination in his subjects". The son interjected by saying "but I told you that you shouldn't buy any result for Economics but Physics" (Makoju et al, 2004). Until less emphasis is laid on paper qualification and people come to place emphasis on the skills acquired in order to function well society, the issue of academic dishonesty will continue to persist (Nwahunanya, 2004).

Consequently, as important as academic integrity is in any educational system, there are some elements that encourage academic dishonesty in our educational system. It has been said that teachers play important role in making school effective and a school cannot be said to be effective if it encourages academic dishonesty. Therefore, there was a need to find out the extent in the perceptions of students to which teachers are involved in academic dishonesty. Furthermore, there was need to find out the various ways that teachers in the views of students are involved in the acts that inject stain in academics.

This study therefore, sought to provide data on the views of senior secondary school students on academic dishonesty perpetuated by teachers. Specifically, data are provided to the following research questions.

1. How often do senior secondary school teachers get involved in academic dishonesty, as perceived by students?

2. What percentage of students perceives teachers as being dishonest and corrupt as examination supervisors and invigilators?

3. In what ways do teachers involve themselves in academic dishonesty in schools?

\section{METHODOLOGY}

The design for the study is survey design. The target population in this study involved senior secondary school student in Rivers State. Therefore, the present analysis was conducted as a sample survey covering all twenty-three Local Government Area (LGA) of Rivers States and consequently a good proportion of the 23 Local Government Areas in Rivers State participated in the study. The Rivers State Senior Secondary Schools Board with particular reference to the 
Department of Planning, Research and Statistics provided information for the sample design, sample size and sample selection. A multi-stage sampling technique at LGA levels and reasonable estimates at school levels was used for sample selection. The sample size used for this study was 1,000 senior secondary school students.

The questionnaire was designed to generate data for analysis on contextual variables including pupil, school and home related factors that impact on academic dishonesty. The questionnaire comprised items on background information like gender; school type; frequency and various ways of teachers' involvement in academic dishonesty. To ensure reliability of the questionnaires, the draft instruments were subjected to pilot testing in three LGA selected on the basis of one from each of the three senatorial districts: Khana, Degama and Port Harcourt. The reliability coefficient obtained for the instrument was 0.87 via the application of Cronbach alpha as a measure of the internal consistency of the instrument. This value is high enough to guarantee the use of the instrument. Administration of instruments was carried out in 12 Local Government Areas, four from each senatorial district. Eight senior secondary schools including four public and four private schools were sampled. One hundred and twenty five students from each of the selected schools completed the questionnaire. The questionnaires were administered in November/December 2016, on SSS 3 students.

\section{Research Question One}

\section{RESULTS}

How often do senior secondary school teachers get involved in academic dishonesty, as perceived by students?

The responses of the students used in this study are presented in Table 1.

Table 1: Percentage analysis of Teachers' Participation in Academic dishonesty as perceived by students

\begin{tabular}{lll}
\hline Responses & Frequency & Percentage (\%) \\
\hline Very often & 320 & 32.0 \\
Often & 237 & 23.7 \\
Occasionally & 327 & 32.7 \\
Never & 116 & 11.6 \\
Total & 1000 & 100 \\
\hline
\end{tabular}

Table 1 indicates that $32.0 \%$ and $23.7 \%$ respectively of the students see their teachers as being very often and often involved in academic dishonesty. A relatively small percentage (32.7\%) sees them involving occasionally. However, a negligible percentage (11.6\%) does not see teachers involving themselves in academic dishonesty. When very often and often are collapsed, one gets a picture as presented in figure 1. 


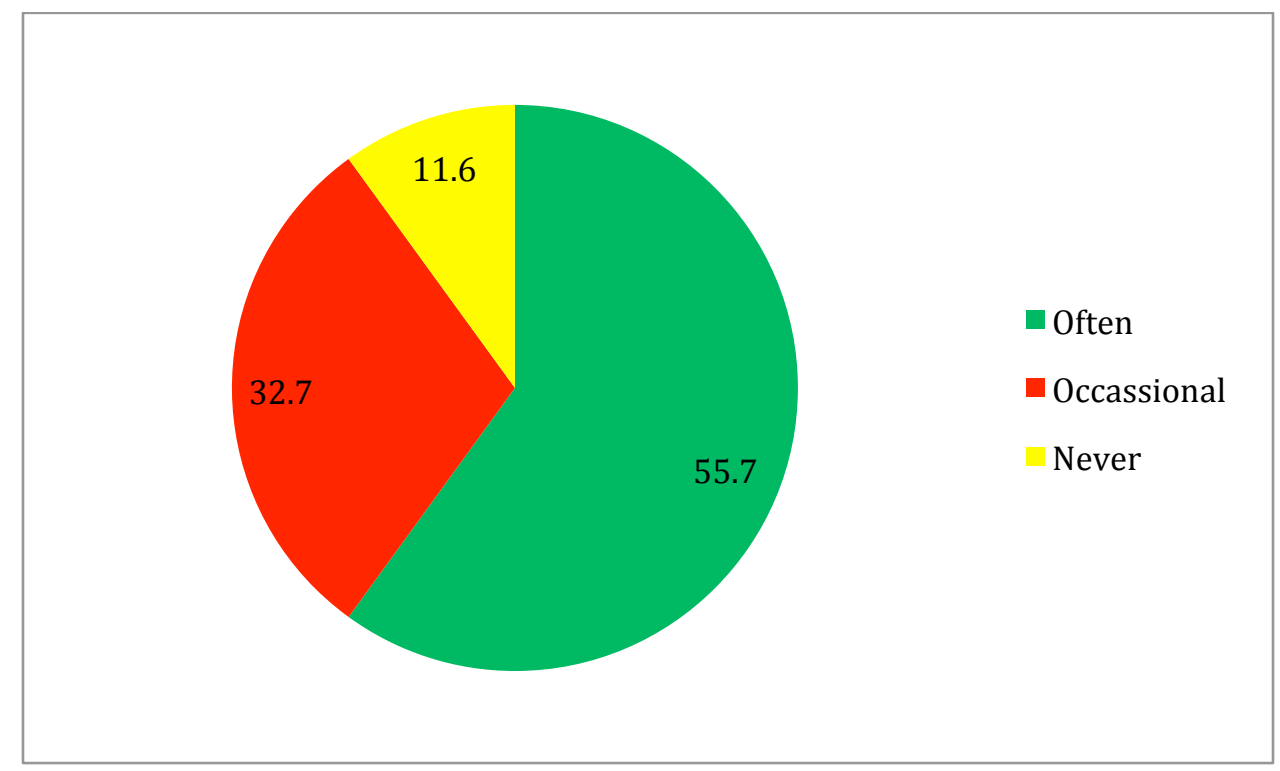

Figure 1: Pie chart showing the frequency of teachers' involvement in academic dishonesty

\section{Research Question Two}

What percentage of students perceives teachers as being dishonest and corrupt as examination supervisors and invigilators?

In response to this question, majority (75.8\%) of the students were of the opinion that their teachers were always dishonest, while serving as supervisors or invigilators. The likelihood is that some teachers always demand for material gratifications from students before they could be passed or helped in solving their problems.

\section{Research Question Three}

In what ways do teachers involve themselves in academic dishonesty in schools?

Table 2: Percentage analysis of various ways teachers involve themselves in Academic dishonesty

\section{Teachers' involvement}

Conspiracy with students during examination

Conspiracy with security officials during examinations

Inflation of continuous assessment/examination scores

Exchange of answers for money

Impersonating student's
$\mathbf{F}$

627

627

750

258
$\%$

Table 2 shows that inflation of continuous assessment/examination scores $(75.0 \%)$ tops the lists of students' opinion about the ways that teachers contribute to academic dishonesty. This followed with conspiracy of teachers with both students and security officials during examination (62.7\%). The table also shows that $25.8 \%$ of the students see exchange of answers for money as another way in which teachers involved themselves in academic dishonesty. One hundred and eighty seven students (18.7\%) indicated that teachers do get involved by impersonating students. 


\section{DISCUSSION}

With respect to the issue of teachers being corrupt, earlier study had indicated that some teachers (supervisors and invigilators) are corrupt. In the study of Makoju, Adewale, Nwargwu and Shuaibu (2004) they concluded that one of the social menaces the present administration is fighting is the issue of corruption. Some people who have one thing or the other with examination are corrupt. They take bribe from students or harass female students sexually before they could allow them pass. Furthermore, the finding that invigilators conspire with both students and security officials during examinations to perpetuate cheating tend to collaborate the findings of previous studies (Onuka \& Obialo, 2004).

The research findings also revealed that most teachers tend to inflate continuous assessment and examination scores. This is in agreement with the findings of STAN, (2011), who reported in a National survey that teachers (and school personnel involved with examination score) unduly inflate examination scores. The results relating to teachers impersonating students also tend to agree with the research the previous reports (e.g. Adewale, 2004). For instance, a candidate registers with his/her names but submits the photograph of another (the mercenary which could be a teacher) with whom arrangement has been made to take the examination on his/her behalf. In this arrangement, the candidate may enter another arrangement with the invigilator to replace the mercenary's photographs with his/her own or the mercenary submits a poorly taken photograph, which will fade within a few months of production. When they fade and replacement is demanded, those of the original candidate are now submitted. These results do not seem to augur well with the school system, especially when viewed from the point of view of the fact that teachers are expected to be character molders.

Furthermore from the observations made by the researchers, parents are not helping teachers' integrity, even when some teachers are not willing to comprise their stand; some parents lure them to do what they do not want to do. There is a specific case, in which due to the craze for paper qualification, a parent bought JAMB result for his son to read medicine, however, he bought a wrong combination. He went with his son to show the result to a professor in one of leading universities in Nigeria and the professor said, "Your child won't be able to read medicine because of wrong combination in his subjects". The son interjected by saying "but I told you that you shouldn't buy any result for Economics but Physics" (Makoju et al, 2004). Until less emphasis is laid on paper qualification and people come to place emphasis on the skills acquired in order to function well society, the issue of academic dishonesty will continue to persist (Nwahunanya, 2004).

\section{CONCLUSION}

One of the precincts of this study is that its scope is on academic dishonesty in which teachers are indicted. Since the study did not gather information on teacher integrity, it will be wrong to conclude that teachers do not have integrity. In addition, it is not all the stakeholders in education information were collected. However, in order to reduce involvement of teachers in academic dishonesty, the following suggestions are recommended.

(1) Teachers should spend more time in preparing students for examinations. If they do it, is likely that teachers would not be intimidated by parents to do what they would not naturally want to do.

(2) Teachers should be contented with what they have because if you are not contented with what you have, you may not likely not participate in aiding and abetting and colluding with students to cheat because of a transient material gains they may receive from the students or their parents. 
(3) Teachers should learn to be proud of their profession. The Teachers Registration Council (TRC) of Nigeria is making effort to teach teachers some ethics of the profession. It is hoped that when and if this is done, most teachers will know what to do when faced with such challenges as being bribed by parents in order to have their children/ward pass; helping students to change marks and sexually harassing female students.

\section{References}

Academic Conduct from University of Saskatchewan Council (2003). Retrieved from http://www.usask.ca/honesty

Adewale, J.G. (2004). Are Head Teachers' Leadership Techniques Predictors of Classroom Teachers' Motivation to Work? A Study in School Effectiveness. West African Journal of Education, 12(2), 12-34.

Donald L., Cabe, M.C. \& Gary, P. (2003). Ten Principles of Academic Integrity Reflecting the Scholarship of Teaching and Learning at the University of Saskatchewan. Saskatchewan: University press.

Federal Government of Nigeria (2004). National Policy on Education (3rd edition) NERDC Press.

Makoju, G.A.E., Adewale, J.G., Nwargwu, R. \& Shuaibu, M. J. (2004). Nigeria Education Sector Analysis: Examination Malpractices. A Report of Education Sector Diagnosis Process.

Nwahunanya, C. (2004). Examination Malpractice: A threat to the Credibility of Distance Education. In Nwahunanya, C. (ed), Distance Education at the Crossroads in Nigeria.

Onuka, A.O. \& Obialo, F.O. (2004). Causes of and solutions to examination malpractices in Nigeria: the perception of some stakeholders. In Omaeze

A. Afemikhe and J. Gbenga Adewale (eds.), Issues in educational Measurement and Evaluation in Nigeria. Institute of Education, p.470-483.

Science Teachers Association of Nigeria (STAN) (2011). Combating the Menace of examination malpractice in Nigeria. Position Paper, No 6. 